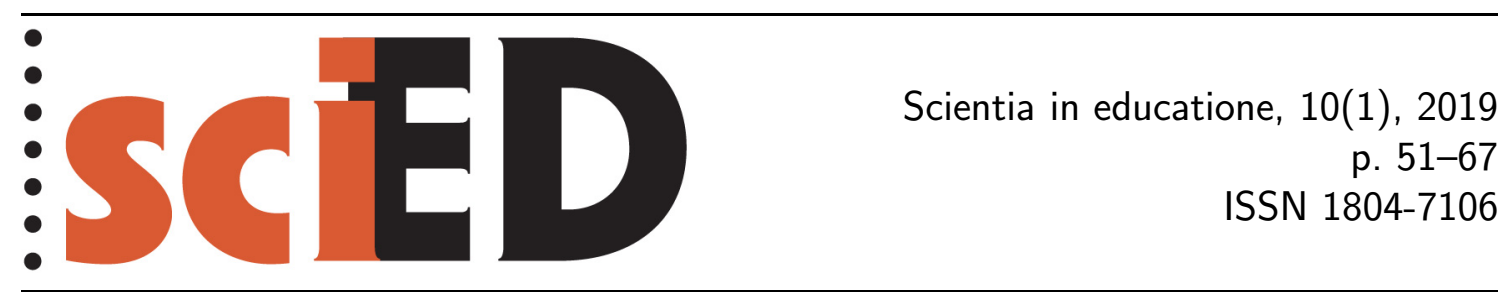

\title{
Hodnocení badatelského přistupu v biologii z pohledu učitelů a žáků gymnázií
}

\author{
Sabina Radvanová, Věra Čižková, Patrícia Martinková
}

\begin{abstract}
Abstrakt
Cílem výzkumu bylo navrhnout, ověřit a reflektovat navržené badatelské aktivity v reálných podmínkách výuky biologie na vyšším gymnáziu jak z pozice žáků, tak jejich učitelů. Vlastnímu šetření předcházelo vytvoření sady dotazníků pro žáky i učitele a pracovních listů pro žáky. Získaná data byla podrobena kvantitativní analýze. Zaznamenané odpovědi žáků v pracovních listech byly zpracovány kvalitativně. Výsledky ukázaly, že učitelé badatelsky orientovanou výuku (BOV) př́liš nevyužívají. Nejčastěji jednotlivé prvky BOV aplikují do praktického cvičení s tím, že se žáky nacvičují spíše nižší úrovně bádání. Navržené badatelské aktivity vnímali učitelé oproti žákům částečně jako zajímavější. Naopak žáci je označili jako náročnější. Obě skupiny respondentů je vnímaly jako př́inosné, avšak zároveň ne vždy zcela srozumitelné. Dále učitelé i žáci uvedli, že by uvítali zejména více návodných informací pro jejich zdárné vyřešení. Žáci, kteří uvedli subjektivní zájem o biologii, vnímali zajímavost, náročnost, srozumitelnost a prŕnosnost signifikantně lépe než žáci, které biologie nezajímá. Naopak ve vnímání výše uvedených kategorií nebyl rozdíl mezi pohlavími žáků. Učitelé i žáci uvedli preferenci samostatného vyhledávání informací žáky ve výuce biologie před pouhým předáváním hotových poznatků.
\end{abstract}

Klíčová slova: badatelsky orientovaná výuka, BOV, gymnázium, biologie, dotazníky, pracovní listy.

\section{The Evaluation of the Inquiry-Based Learning in Biology Classes from the Grammar School Teachers' and Students' Point of View}

\begin{abstract}
The aim of the research was to design, verify and reflect upon the suggested inquiry-based activities in a real upper-secondary biology class settings, considering both the students' and the teachers' point of view. Firstly, a set of questionnaires for students as well as for teachers and worksheets for students were created. The obtained data were analysed quantitatively, while the students' responses in the worksheets were analysed qualitatively. The results indicate that teachers make only sporadic use of inquiry-based learning (IBL). They most commonly incorporate some components of the IBL into practical exercises, practising lower levels of research with their students. Teachers considered the suggested
\end{abstract}


inquiry-based activities more interesting than the students did. The students, on the other hand, viewed them as more demanding. Both groups of respondents considered them beneficial, although not always fully comprehensible. Furthermore, both students and teachers indicated they would welcome more leading information which would enable them to finish the assigned activities successfully. The students who stated their subjective interest in biology were much more appreciative of how intriguing, challenging, comprehensible and beneficial the activities were, as opposed to those students who were ostensibly not interested in biology. On the other hand, there was no difference in the perception of the above mentioned categories if we use the students' gender as a criterion. Both the teachers and students generally expressed their belief that students should look up the information by themselves in biology classes rather than being presented with complete facts.

Key words: inquiry-based learning, IBL, grammar school, biology, questionnaires, worksheets.

Obsah a výzkumný záměr tohoto příspěvku navazuje na práci Radvanové et al. (2018), jejímž cílem bylo zprostředkovat pedagogické veřejnosti souhrnný pohled gymnaziálních učitelů biologie na badatelsky orientovanou výuku (BOV) ve školní praxi. Zároveň je v této studii přibližzen současný pohled na BOV u nás i v zahraničí se zřetelem na biologické práce. Cílem následujícího výzkumu je provést hlubší sondu do využívání BOV z různých úhlů pohledu na základě využití konkrétních badatelských aktivit vlastní tvorby. Zpětná vazba žáků a jejich učitelů byla zjištována prostřednictvím sady vytvořených dotazníků.

Závěry ze široce založených výzkumů ukazují relativně se zhoršující trend biologických znalostí žáků i jejich schopností samostatného uvažování (Blažek \& Příhodová, 2016). Tento stav poukazuje na nutnost rozvíjení dovedností, které v oblasti př́rodních věd odrážejí schopnost žáků klást si otázky, hledat na ně odpovědi a vyhodnocovat získané údaje. Orientace na bádání se proto jeví pro přírodní vědy jako atraktivní. Pro zdárnou implementaci badatelství do školní praxe je však nutné, aby učitelé opustili zaběhlý systém výuky, měli důvěru ve schopnosti dorůstající generace, připravili se na možné nezdary, rozpoznali úspěchy, ocenili samostatnost (Rastede, 2016). Hošpesová (2016) však zároveň upozorňuje na nutnost analýzy didaktických přístupů zahrnujících bádání žáků, která by měla kriticky vyhodnotit přinosy, slabiny a obtíže, jež se v takovém vyučování vyskytnou.

$\mathrm{V}$ rámci našeho výzkumu byl proto vytvořen soubor aktivit a doprovodných materiálů, které jsou zaměřeny na porozumění vědeckým postupům a získávání nových vědomostí a dovedností žáků s důrazem na funkční využívání př́írodovědných poznatků. Tématem je komplexní pohled na úlohu vody v procesu vylučování odpadních látek ve vztahu k člověku. Této problematice zatím nebylo v badatelských projektech věnováno mnoho pozornosti. Projekty a práce jiných autorů nejsou vztaženy přímo $\mathrm{k}$ člověku, ale přinášejí pohled na vodu spíše z hlediska biologického (Heflich, Dixon \& Davis, 2001), chemického (Comeaux \& Huber, 2001; Marx et al., 2004; Wu \& Krajcik, 2006) či fyzikálního (Huber \& Moore, 2001; Jarvis, 2008). Důraz byl kladen na využívání kognitivních postupů vyšší úrovně, podobně jako je tomu u úloh projektu OECD/PISA ${ }^{1}$ (Blažek, 2017). Pozornost byla věnována také tomu, aby jednotlivé aktivity obsahovaly prvky vycházející z různých vzdělávacích oblastí

\footnotetext{
${ }^{1}$ Organization for Economic Cooperation Development/Programme for International Student Assessment
} 
a též pomáhaly rozvíjet klíčové kompetence vymezené v RVP $\mathrm{G}^{2}$. Dále bylo snahou podporovat především vyšší úrovně bádání, tzn. nasměrované a otevřené, jehož jednotlivé kroky je potřeba se žáky postupně nacvičovat, jak také doporučují Wenning (2005, 2010), Činčera (2013) a Kireš et al. (2016). Výsledky studie provedené např. Rokosem et al. (2013) upozorňují na skutečnost, že se z laboratorních prací na středních školách postupně vytratily prvky objevování, bádání a jejich průběh má charakter pouhé posloupnosti zadaných činností, čímž ztrácí motivační i vzdělávací funkci. Autoři dále zjistili, že žáci nemají příliš v oblibě použivání pracovních listů pro značnou formalizaci. Kireš et al. (2016) proto doporučují při realizaci badatelských aktivit používat modifikované formy pracovních listů za účelem vedení žáků k psaní si poznámek a otázek, které rozvíjejí jejich vlastní bádání, čehož bylo využito i v našem výzkumu.

V současné pedagogické literatuře bývá nejčastěji využívaný čtyřúrovňový typ bádání, který v sobě zahrnuje následující kategorie badatelského přístupu: 1. potvrzující bádání, 2. strukturované bádání, 3. řízené bádání, 4. otevřené bádání. Jednotlivé úrovně BOV se od sebe odlišují na základě míry aktivního zapojení žáků do výuky a vnějšího řízení výuky učitelem (Banchi \& Bell, 2008). Pro potřeby našeho výzkumu však byla využívána pětiúrovňová hierarchie badatelských dovedností podle projektu ESTABLISH ${ }^{3}: 1$. interaktivní diskuse/demonstrace, 2. potvrzující bádání, 3. řízené bádání, 4. nasměrované bádání, 5. otevřené bádání (Kireš et al., 2016). Postupné osvojování badatelských dovedností žáky však bezprostředně vyžaduje realizaci jednotlivých kroků badatelského cyklu, jehož koncept vychází ze vzdělávacího modelu 5E: 1. Engage/Zjištování, 2. Explore/Zkoumání, 3. Explain/Vysvětlování, 4. Elaborate/Rozpracování, 5. Evaluate/Vyhodnocení (Science Education Curriculum Study). Později byl tento model přepracován a rozšřřen na model $7 \mathrm{E}$, ve kterém je zdůrazněna i fáze zjištování prvotních poznatků žáků (Elicit/Získávání), resp. fáze transferu získaných poznatků na nové situace (Extend/Rozšiřrení) (Eisenkraft, 2003). Ke klasifikaci badatelských dovedností do jednotlivých badatelských kroků byl v našem výzkumu využit rozšiřřený $5 \mathrm{E}$ model, který vznikl sloučením obou výše popsaných modelů: 1. Engage-Elicit/Zapojení a Zjištování, 2. Explore/Zkoumání, 3. Explain/Vysvětlování, 4. Elaborate-Extend/Rozpracování a Rozšǐření, 5. Evaluate/Vyhodnocení (Kireš et al., 2016).

\section{CÍl vÝZKUMU}

Cílem výzkumu bylo navrhnout, ověřit a reflektovat navržené badatelské aktivity ve výuce biologie na vyšším gymnáziu. $\mathrm{V}$ souladu s vymezeným cílem byla formulována hlavní výzkumná otázka: „Jaká je využitelnost vytvořených badatelských aktivit v podmínkách reálné školní výuky biologie z pohledu žáků a jejich učitelů?" Pro její zodpovězení byly stanoveny následující dílčí výzkumné otázky: 1. Jak reflektují žáci a učitelé vytvořené badatelské aktivity z hlediska jejich zajímavosti, náročnosti, srozumitelnosti a přínosnosti?, 2. Jak reflektují žáci a učitelé vytvořené badatelské aktivity z hlediska časového rámce, informačního zázemí a dostupnosti materiálů a pomůcek?, 3. Jak reflektují žáci dle pohlaví a přiznaného subjektivního zájmu či nezájmu o biologii vytvořené badatelské aktivity z hlediska jejich zajímavosti, náročnosti, srozumitelnosti a přínosnosti?, 4. Do které vyučovací jednotky učitelé nejčastěji BOV zařazují?, 5. Které kroky, jež odpovídají badatelskému cyklu,

\footnotetext{
${ }^{2}$ Rámcový vzdělávací program pro gymnázia

${ }^{3}$ European Science and Technology in Action: Building Links with Industry, Schools and Home
} 
učitelé se žáky nejčastěji nacvičují ve výuce biologie a do které vyučující jednotky je zařazují?, 6. Který způsob získávání informací preferují žáci ve výuce biologie?

\section{METODIKA VÝZKUMU}

\section{PLÁN VÝZKUMU A VÝZKUMNÝ VZOREK}

Prvním krokem bylo ověření badatelských aktivit a následné vyplnění dotazníků jak žáky, tak učiteli. Získaná data byla podrobena kvantitativní analýze. Zaznamenané odpovědi žáků v pracovních listech byly zpracovány kvalitativně.

Jelikož měli jednotliví učitelé zapojení do výzkumu různé zkušenosti s badatelskou výukou, obdrželi všichni potřebné materiály a přesné instrukce $\mathrm{k}$ průběhu celého ověrování jednotlivých badatelských aktivit. Tím mělo být docíleno toho, že všichni žáci mají zajištěné stejné podmínky.

Vytvořené výukové materiály a výzkumné nástroje (dotazníky pro žáky a dotazníky pro učitele) byly nejprve pilotovány na dvou záměrně vybraných pražských gymnáziích vždy $\mathrm{v}$ jedné tř́ídě $\mathrm{v}$ rámci vyučovacích hodin, a to $\mathrm{v}$ plném rozsahu. Celkem tedy bylo oveř̌eno pět aktivit: „Sůl nad zlato?", „Vodní špeditéři“, „Čistička v lidském těle“, „Souměrně či protisměrně?" a „Ledviny nejsou na všechno samy“. ${ }^{4}$ Po pilotáži došlo k jejich následné úpravě a zpřesnění některých formulací do finální podoby. Finální ověřování probíhalo od roku 2013 do roku 2014 na sedmi záměrně ${ }^{5}$ vybraných pražských státních gymnáziích vždy v jedné tř́dě v rámci vyučovacích hodin. Ověřeny byly čtyři aktivity. ${ }^{6}$ Zaměřením škol byla zastoupena gymnázia všeobecná, humanitní i jazyková. Výzkumný vzorek tvořili žáci osmi tříd ${ }^{7}$ 3. ročníku gymnázia a odpovídajících ročníků víceletých gymnázií. Celkem se jednalo o 228 žáků, z toho 111 dívek a 117 chlapců. ${ }^{8}$ Ověřování se účastnilo sedm učitelů, z toho pět žen a dva muži.

\section{BADATELSKY ORIENTOVANÁ VÝUKA A TVORBA BADATELSKÝCH} AKTIVIT

Pro potřeby našeho výzkumu byla využívána pětiúrovňová hierarchie badatelských dovedností podle projektu ESTABLISH (Kireš et al., 2016). Ke klasifikaci badatelských dovedností do jednotlivých kroků byl využit rozššřený 5E model (Kireš et al., 2016).

Vyučovaná látka, tematicky zaměřená na vylučování člověka, byla pro badatelsky vedenou výuku rozvržena do šesti vyučovacích hodin a zpracována do pěti samostatných (samonosných) aktivit. Každá aktivita byla opatřena pracovními materiály

\footnotetext{
${ }^{4}$ Jednotlivé badatelské aktivity a doprovodné materiály jsou uloženy jako elektronická př́loha článku na webových stránkách časopisu.

${ }^{5} \mathrm{~S}$ tímto faktem souvisí i skutečnost, že nebylo pokaždé možné dodržet všechny relevantní znaky určující záměrný výběr, proto byl za hlavní znak pro výběr tříd do výzkumu považován věk žáků (17-18 let), stejný ročník (3. ročník gymnázia a odpovídající ročníky víceletých gymnázií) a stejné podmínky pro výuku. Tato skutečnost byla dána do jisté míry ochotou a schopností daného vyučujícího učit tematický celek badatelským přístupem, popř. jeho úvazkem či zaměřením a typem školy.

${ }^{6} \mathrm{Z}$ vytvořených aktivit pro badatelskou výuku nebyla během finálního ověřování zařazena do výuky z časových důvodů aktivita „Souměrně či protisměrně?“"

${ }^{7} \mathrm{Na}$ Gymnáziu 7 probíhalo ověřování 2 roky a účastnil se ho vždy stejný učitel.

${ }^{8}$ Podrobnější demografické charakteristiky žáků (viz obr. 1, 2) jsou uloženy jako elektronická př́loha článku na webových stránkách časopisu.
} 
pro žáky a metodickými materiály pro učitele. Za organizační formu vyučování bylo zvoleno vyučování skupinové. Učivo bylo žákům předkládáno prostřednictvím výzkumné metody.

Vytvořené pracovní materiály pro jednotlivé aktivity byly rozděleny do čtyř částí. První z nich byla hypotéza, které mohla předcházet motivace. Následovalo šetření, díky němuž žáci získali výsledky. Uváděli je v další části pracovního materiálu, za kterou následoval závěr šetření. Některé části pracovních materiálů žáci vypracovávali v rámci vyučovacích hodin, na jiných mohli pracovat doma v rámci domácí př́pravy. Jednotlivé aktivity jsou samonosné, lze je tedy použít i samostatně.

Součástí vytvořených pracovních materiálů je metodická příručka pro učitele. Ta obsahuje úvodní část s popisem celé vyučované látky, rozebrané znaky badatelsky orientované výuky, didaktický rozbor obsahu a dále obecný metodický postup. Je zde uveden seznam všech aktivit a návrh na hodnocení. Hlavní částí příručky pro učitele jsou metodické návody rozpracované pro každou aktivitu zvlášt. U jednotlivých aktivit lze najít návrh postupu, časovou dotaci, seznam potřebných a finančně nenáročných pomůcek.

\section{VÝZKUMNÝ NÁSTROJ}

Pro zjištění zpětné vazby od žáků a učitelů zapojených do ověřování navržených badatelských aktivit byla vytvořena sada dotazníků, kterou respondenti vyplnili po skončení výzkumu. Dotazníky se lišily pouze v první části, a to v počtu demografických položek. Ve druhé části dotazníků respondenti vyjadřovali v sedmi otázkách míru svého souhlasu s jednotlivými tvrzeními týkajícími se jednak zajímavosti, náročnosti, ${ }^{9}$ srozumitelnosti ${ }^{10}$ a př́nosnosti jednotlivých badatelských aktivit a jednak organizačních záležitostí, tj. časový rámec, dostatek informací, materiálů a pomůcek. Pokud chtěli ještě něco dodat k volbě své odpovědi, měli možnost se vyjádřit v poznámkách u každého tvrzení. Tato část dotazníku byla shodná pro žáky i učitele z důvodu srovnání jejich odpovědí na stejné otázky.

V dotazníku pro reflektování míry využívání BOV v biologii byly hodnoceny položky, které zjištovaly četnost využívání badatelsky orientované výuky v biologii a konkrétních badatelských dovedností, které odpovídají jednotlivým krokům badatelského př́istupu (cyklu). Hodnoceny byly také osobní preference žáků pro zpơsob získávání informací ve výuce.

\section{VÝVOJ VÝUKOVÝCH MATERIÁLŮ A VÝZKUMNÉHO NÁSTROJE}

Celkem byly vytvořeny tři verze výukových materiáli̊ a výzkumného nástroje (dotazníků) před dosažením finální podoby, u kterých byla zjištována obsahová validita. První verze byla konzultována s pěti gymnaziálními učiteli biologie a pěti vysokoškolskými pedagogy se zaměřením na didaktiku biologie, odbornou biologii a kvantitativní metodologii pedagogického výzkumu. Na základě získaných připomínek byla

\footnotetext{
${ }^{9} \mathrm{~V}$ této studii je na náročnost nahlíženo jako na subjektivní vyjádření žáků a učitelů k vlastnostem textu (tj. z hlediska jazykového, obsahového a grafického). Zatímco na obtížnost je nahlíženo v souladu s vymezením, tak jak uvádí Průcha (1987), tedy jako na souhrn vlastností textu, které v něm objektivně existují, ovlivňují jeho percepci a zpracování informací učícím se subjektem. Je možno ji vyjádřit $\mathrm{v}$ podobě kvantitativních parametrů.

${ }^{10} \mathrm{Na}$ srozumitelnost je $\mathrm{v}$ této studii nahlíženo jako na míru schopnosti žáků samostatně řešit dílčí úkoly v pracovních materiálech pro jednotlivé badatelské aktivity.
} 
vytvořena druhá verze, která byla pilotně ověrována (viz výše), a na základě získaných výsledků byla vytvořena konečná, třetí verze, která byla ověřována finálně.

Reliabilita dotazníků byla ověřena korelací průměrných odpovědí mezi žáky a odpovědí jejich učitelů získaných při finálním ověřování. Hodnota korelačního koeficientu činila 0,39 pro dotazník reflektující badatelské aktivity, pro dotazník reflektující míru využívání BOV v biologii byla 0,67 .

\section{ZPRACOVÁNÍ DAT}

Pro zodpovězení stanovených výzkumných otázek a zpracování dat bylo primárně využito přístupů kvantitativní analýzy. Míra souhlasu respondentů byla u jednotlivých položek dotazníků převedena do podoby číselných kódů (skórů), ${ }^{11}$ a to: 1 zcela souhlasím, 2 - spíše souhlasím, 3 - spíše nesouhlasím, 4 - zcela nesouhlasím. Respondenti měli možnost zaškrtnout také volbu „nemohu posoudit“. Statistické vyhodnocení dat bylo provedeno v programu MS Excel 2016 (Microsoft). Podíly jednotlivých skórů byly u jednotlivých položek a skupin vizuálně zhodnoceny na základě skládaných grafů, tzv. stacked graphs. Pro jednotlivé položky a dané skupiny byly spočítány průměrné hodnoty a směrodatné odchylky. Porovnání mezi dvěma skupinami, např̀. dle pohlaví žáků, resp. přiznaného subjektivního zájmu či nezájmu žáků o biologii, bylo provedeno pomocí dvouvýběrového $t$-testu. $V$ případě existence vzájemné závislosti uvnitř dvojic, tj. žáci a učitelé, byl aplikován párový $t$-test. V případě, že byly najednou porovnány výsledky ve více položkách, byly dosažené hladiny významnosti korigovány pomocí Bonferroniho korekce na mnohonásobná porovnání. Rozdíly byly považovány za statisticky významné, pokud dosažená hladina testu ( $p$-hodnota) byla menší než zvolená $5 \%$ hladina významnosti $(p<0,05)$. Pro posouzení míry věcné významnosti (effect size) bylo použito Cohenovo $d$. Pro posouzení věcné významnosti byly rozdíly považovány za velmi malé, pokud $d<0,20$; malé pro $d$ mezi 0,20 a 0,50 včetně; střední pro $d$ mezi 0,50 a 0,80 včetně; a velké pro $d>0,80$ (Cohen, 1988; Soukup, 2013).

Pro posouzení závislostí mezi odpověd’mi žáků a jejich učitelů bylo využito Pearsonova korelačního koeficientu $r$, přičemž hodnoty vyšší než 0,50 byly považovány za velké (Cohen, 1988). Statistická významnost korelačního koeficientu byla testována za využití Studentova t rozdělení, dosažené hladiny významnosti byly opět korigovány na mnohonásobná porovnání a porovnány se zvolenou $5 \%$ hladinou významnosti. Pro posouzení věcné významnosti byly hodnoty korelačního koeficientu považovány za velmi malé, je-li $r<0,10$; malé je-li $r$ mezi 0,10 a 0,30 včetně; střední je-li $r$ mezi 0,30 a 0,50 včetně; a velké je-li $r>0,50$ (Cohen, 1988; Soukup, 2013).

Kvantitativní analýza získaných dat byla doplněna o kvalitativní analýzu zaznamenaných odpovědí žáků v pracovních listech. Odpovědi žáků byly posuzovány ve vztahu $\mathrm{k}$ předem definovaným modelovým odpovědím, které byly aktualizovány na základě zkušeností z proběhlé pilotáže vytvořených pracovních materiálů pro jednotlivé badatelské aktivity. Za pomoci techniky konstantní komparace byl vytvořen kategorizovaný seznam kódů (Šed’ová, 2014). Výsledky této analýzy, které jsou v této studii prezentovány pouze doplňkově, odhalily mnohé nedostatky, kterých se žáci při řešení pracovních listů opakovaně dopouštěli.

\footnotetext{
${ }^{11}$ Pět úrovní na škále nebylo zvoleno z důvodu časté inklinace respondentů k neutrální hodnotě během validace výzkumného nástroje, čemuž byla snaha se vyhnout během finálního šetření. Jelikož se ne všichni žáci či učitelé měli možnost vyjádřit ke všem položkám dotazníků, byla tato skutečnost vyřešena přidáním úrovně „nemohu posoudit“ (např. všichni žáci nebyli fyzicky přítomni na ověřování příslušné badatelské aktivity či nenavštěvují výběrový seminář z biologie apod.).
} 


\section{VÝSLEDKY VÝZKUMU A JEJICH DISKUSE}

\section{KVANTITATIVNÍ ANALÝZA}

\section{REFLEKTOVÁNÍ VYTVOŘENÝCH BADATELSKÝCH AKTIVIT ŽÁKY A UČITELI Z HLEDISKA JEJICH ZAJÍMAVOSTI, NÁROČNOSTI, SROZUMITELNOSTI}

A PřínOSNOSTI

Analýzy $^{12}$ se zabývaly mírou souhlasu se sledovanými kategoriemi, tj. zajímavost, náročnost, srozumitelnost, přínosnost, u jednotlivých badatelských aktivit.

Učitelé vnímají některé badatelské aktivity jako signifikantně zajímavější než jejich žáci (konkrétně se jedná o aktivity Sůl nad zlato? a Ledviny nejsou na všechno samy). Naopak žáci reflektují všechny badatelské aktivity jako signifikantně náročnější. U žáků i učitelů je pak patrné kladné vnímání jejich přínosnosti, avšak zároveň se jim tyto aktivity jeví ne vždy zcela srozumitelné. Obě uvedená zjištění nejsou statisticky signifikantní (viz tab. 1).

Tab. 1: Průměrné skóre reflexe míry zajímavosti, náročnosti, srozumitelnosti a př́nosnosti jednotlivých badatelských aktivit z pohledu žáků a učitelů

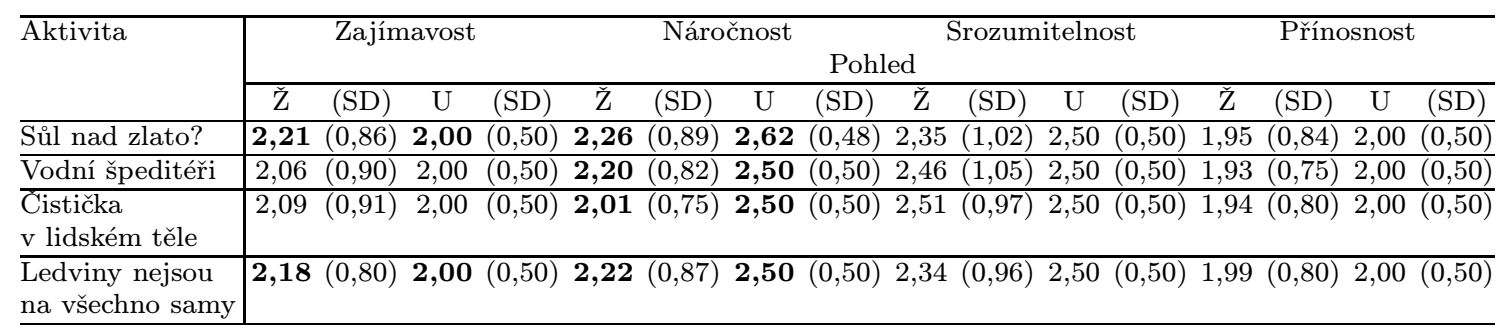

Poznámky: SD (standard deviation) - směrodatná odchylka, Ž - žák, U - učitel. Výsledky párového $t$-testu viz tab. P1 a obr. 3-6, korelační analýzy viz tab. P2 a obr. 3-6 v př́loze. Sledované kategorie, u kterých se statisticky významně lišilo reflektování mezi dvěma skupinami i po korekci, jsou zvýrazněné tučně.

Relativní zajímavost a př́nosnost navržených badatelských aktivit pro obě skupiny respondentů si lze do jisté míry vysvětlit jejich zaměřením především na biologii člověka, která patří u žáků i učitelů k dlouhodobě nejoblíbenějším oblastem biologie (Sjøberg \& Schreiner, 2010; Malcová \& Janštová, 2018). Navíc byl kladen důraz na propojení učiva různých vědních oborů, tedy nejenom biologických, a na přesah do každodenního života žáků.

Většina navržených aktivit rozvíjí u žáků především vyšší úrovně bádání (Kireš et al., 2016). Nejsou-li tedy žáci zvyklí samostatně pracovat, mohou se jim jevit jako náročné, a i učitelům jako ne vždy zcela srozumitelné. Mnohé výzkumy naznačují (Kirschner, Sweller \& Clark, 2006 či Radvanová et al., 2018), že právě nedostatečné znalosti a dovednosti žáků pro bádání jsou uváděny učiteli jako jedny z možných důvodů nevyužívání BOV ve výuce v plném rozsahu. Těžko je však lze od žáků očekávat, pokud budou učitelé BOV opouštět z důvodu nedostatečných kompetencí pro její realizaci (Dostál, 2015a, 2015b). Pokud tedy obdobné aktivity učitelé ve výuce př́liš nevyužívali, nevědí, co mohou od žáků očekávat. Do jisté míry však mají od žáků vyšší očekávání, a to možná z důvodu, že se jedná o žáky gymnázií, tudíž žáky výběrové. Některé studie též ukazují (Vojtíšková, 2011), že učitelovo hodnocení je výrazně ovlivněno preferenčními postoji. Čím více učitel vnímá žáka za schopného, pilného a sympatického, tím je žákův výkon, a tím pádem i prospěch, lepší. Stokking

\footnotetext{
${ }^{12}$ Podrobnější statistické analýzy získaných dat v podobě shrnujících tabulek a skládaných grafů jsou uloženy jako elektronická př́loha článku na webových stránkách časopisu.
} 
et al. (2004) se ve své studii zabývají schopností učitelů hodnotit vědecké dovednosti žáků a ukazuje se, že učitelé se liší v názoru na to, co si představují pod pojmem kritérium kvality.

Proto by bylo vhodné na základě námi zjištěných skutečností, aby učitelé měli k dispozici co nejvíce krátkých úloh, které by samostatně nacvičovaly jednotlivé dovednosti (též Fučík \& Kuchař, 2012; Ješková et al., 2016; Radvanová et al., 2018). Lze konstatovat, že postupné rozvíjení a zvládnutí jednotlivých badatelských kroků a dovedností by velmi prospělo i časovému zvládnutí náročnějších a komplexnějších badatelských úloh.

\section{REFLEKTOVÁNÍ VYTVOŘENÝCH BADATELSKÝCH AKTIVIT ŽÁKY A UČITELI Z HLEDISKA ČASOVÉHO RÁMCE, INFORMAČNÍHO ZÁZEMÍ A DOSTUPNOSTI MATERIÁLŮ A POMŮCEK}

Zajímalo nás, do jaké míry mají žáci na řešení jednotlivých badatelských aktivit dostatek poskytnutého času a zda jim k tomu nechybí žádné informace, popř. materiály a pomůcky.

Z tab. 2 je patrné, že žáci vnímají sledované kategorie signifikantně lépe, než uvedli jejich učitelé. Obě skupiny respondentů se nejvíce názorově rozcházely u kategorie dostatku poskytnutých materiáli̊ a pomůcek. Nutno je ovšem dodat, že by žáci i učitelé uvítali zejména více návodných informací pro zdárné vyřešení všech aktivit, rozdíl mezi skupinami zde byl statisticky signifikantní pouze pro první aktivitu.

Učitelé tudíž opět nevědí, co mají od žáků při řešení badatelských aktivit očekávat. Obecně je možno říci, že pokud je aktivita pro žáka náročnější, a ne vždy zcela srozumitelná, o to více bude potřebovat návodných informací pro její zdárné vyřešení. Jak už bylo řečeno, jednalo se o aktivity nacvičující u žáků především vyšší úrovně bádání, a proto jim nebyly záměrně poskytnuty všechny údaje. Všechny potřebné materiály a pomůcky však žákům byly poskytnuty.

Tab. 2: Průměrné skóre reflexe míry dostatku času, úplnosti informací a dostatku poskytnutých materiálů a pomůcek pro řešení jednotlivých badatelských aktivit z pohledu žáků a učitelů

\begin{tabular}{|c|c|c|c|c|c|c|c|c|c|c|}
\hline \multirow[t]{2}{*}{ Aktivita } & \multicolumn{3}{|c|}{$\begin{array}{c}\text { Dostatek } \\
\text { poskytnutého času }\end{array}$} & \multicolumn{4}{|c|}{$\begin{array}{c}\text { Uplnost } \\
\text { informací } \\
\text { Pohled }\end{array}$} & \multicolumn{3}{|c|}{$\begin{array}{c}\text { Dostatek poskytnutých } \\
\text { materiálů a pomůcek }\end{array}$} \\
\hline & žáka $(\mathrm{SD})$ & učitele & $(\mathrm{SD})$ & žáka & $(\mathrm{SD})$ & učitele & $(\mathrm{SD})$ & žáka $(\mathrm{SD})$ & učitele & $(\mathrm{SD})$ \\
\hline Sůl nad zlato? & $\mathbf{2 , 0 2}(0,82)$ & 2,25 & $(0,43)$ & 2,23 & $(0,99)$ & 2,50 & $(0,50)$ & $\mathbf{2 , 0 2}(0,78)$ & 2,25 & $(0,43)$ \\
\hline Vodní špeditéři & $2,11 \quad(0,75)$ & 2,25 & $(0,43)$ & 2,36 & $(0,93)$ & 2,50 & $(0,50)$ & $\mathbf{2 , 0 9}(0,78)$ & 2,25 & $(0,43)$ \\
\hline Čistička v lidském těle & $2,25 \quad(0,69)$ & 2,25 & $(0,43)$ & 2,38 & $(0,92)$ & 2,50 & $(0,50)$ & $\mathbf{2 , 0 8}(0,79)$ & 2,25 & $(0,43)$ \\
\hline Ledviny nejsou na všechno samy & $2,10(0,73)$ & 2,25 & $(0,43)$ & 2,33 & $(0,93)$ & 2,50 & $(0,50)$ & $\mathbf{2 , 0 9}(0,77)$ & 2,25 & $(0,43)$ \\
\hline
\end{tabular}

Poznámky: SD (standard deviation) - směrodatná odchylka. Výsledky párového t-testu viz tab. P1 a obr. 7-9, korelační analýzy viz tab. P2 a obr. 7-9 v př́loze. Sledované kategorie, u kterých se statisticky významně lišilo reflektování mezi dvěma skupinami i po korekci, jsou zvýrazněné tučně.

\section{REFLEKTOVÁNí BADATELSKÝCH AKTIVIT Z HLEDISKA JEJICH ZAJÍMAVOSTI, NÁROČNOSTI, SROZUMITELNOSTI A PŘÍNOSNOSTI DLE POHLAVÍ ŽÁKŮ}

Úkolem bylo zjistit míru souhlasu se sledovanými kategoriemi, tj. zajímavost, náročnost, srozumitelnost, přínosnost, u jednotlivých badatelských aktivit dle pohlaví žáků. 
Při bližším pohledu na vnímání jednotlivých badatelských aktivit dle pohlaví žáků lze zjistit, že mezi dívkami a chlapci není statisticky signifikantní rozdíl v reflektování sledovaných kategorií, tj. zajímavosti, náročnosti, srozumitelnosti a přínosnosti, viz tab. 3.

V rámci proběhlého výzkumu lze tedy obecně usuzovat, že jednotlivé badatelské aktivity svým zaměřením a typologií nijak významně neznevýhodňovaly konkrétní pohlaví. Je možné proto souhlasit s názorem autorů Akcay a Yager (2016), že BOV je vhodná pro obě pohlaví žáků.

Tab. 3: Průměrné skóre reflexe míry zajímavosti, náročnosti, srozumitelnosti a př́nosnosti jednotlivých badatelských aktivit z pohledu dívek a chlapců

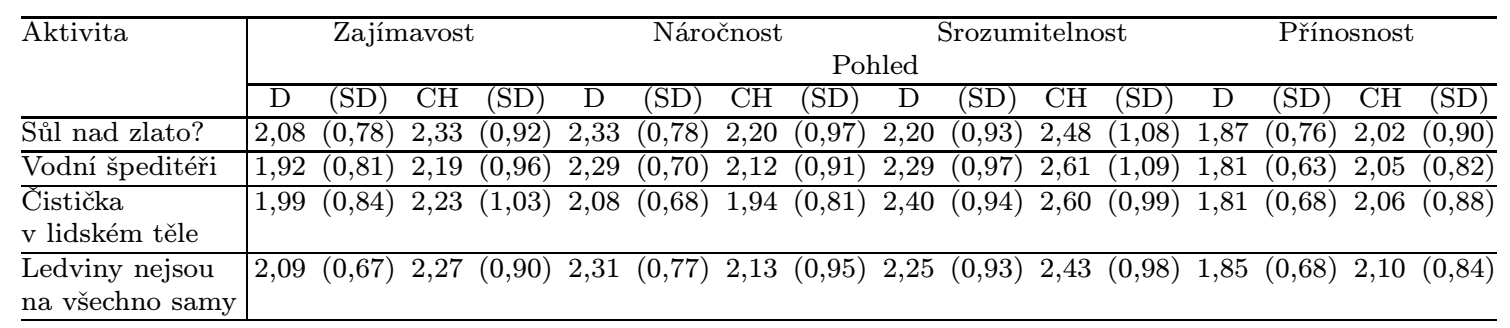

Poznámky: SD (standard deviation) - směrodatná odchylka, D - dívka, CH - chlapec. Výsledky dvouvýběrového $t$-testu viz tab. P3 a obr. 10-13 v př́loze.

\section{REFLEKTOVÁNí BADATELSKÝCH AKTIVIT Z HLEDISKA JEJICH ZAJÍMAVOSTI, NÁROČNOSTI, SROZUMITELNOSTI A PŘÍNOSNOSTI DLE PŘIZNANÉHO SUBJEKTIVNÍHO ZÁJMU ČI NEZÁJMU O BIOLOGII}

Výzkum se dále zabýval mírou souhlasu se sledovanými kategoriemi, tj. zajímavost, náročnost, srozumitelnost, př́nosnost, u jednotlivých badatelských aktivit dle přiznaného subjektivního zájmu o biologii.

Žáci, kteří uvedli subjektivní zájem o biologii, ${ }^{13}$ vnímají většinu sledovaných kategorií, tj. zajímavost, náročnost, srozumitelnost a přínosnost, statisticky signifikantně lépe než žáci, které biologie nezajímá (viz tab. 4).

Tab. 4: Průměrné skóre reflexe míry zajímavosti, náročnosti, srozumitelnosti a př́nosnosti jednotlivých badatelských aktivit z pohledu žáků se zájmem a nezájmem o biologii

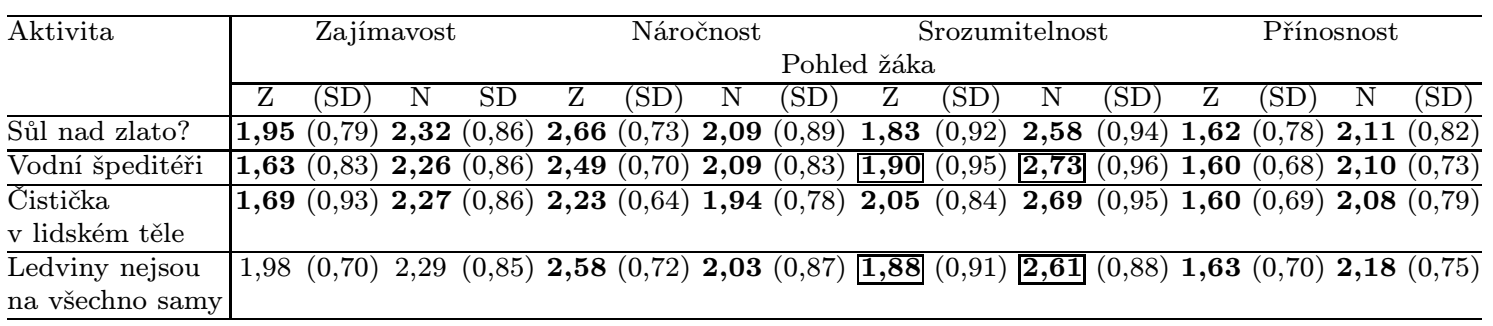

Poznámky: SD (standard deviation) - směrodatná odchylka, Z - zájem, N - nezájem. Výsledky dvouvýběrového t-testu viz tab. P4 a obr. 14-17 v př́loze. Sledované kategorie, u kterých se statisticky významně lišilo reflektování mezi dvěma skupinami i po korekci, jsou zvýrazněné tučně. Pokud bylo $d>0,80$, jsou příslušné hodnoty orámovány.

\footnotetext{
13 Žák projevil zájem o biologii, pokud odpověděl kladně alespoň na jednu z následujících nabízených možností: maturita z biologie, studium na vysoké škole s přírodovědným zaměřením, účast na Biologické olympiádě či jiných soutěžích s biologickým zaměřením, účast na přednáškách, besedách či konferencích s biologickou tematikou, četba biologické literatury, návštěva biologických kroužků.
} 
Ukazuje se tak, že žáci již mají v tomto věku vyhraněné zájmy a většinou mají jasnou představu o tom, jakým směrem se budou jejich budoucí studia dále ubírat. Zároveň jsou i tito žáci ochotnější vynaložit potřebné úsilí, aby podali dobré výkony, což se projevilo zejména $\mathrm{v}$ jejich zodpovědnosti a pečlivosti při zpracování odpovědí v pracovních listech.

\section{ZAŘAZOVÁNí BOV UČITELI DO VYUČOVACÍCH JEDNOTEK}

Byla zjištována míra zkušenosti s realizací BOV ve vyučovacích jednotkách.

Z tab. 5 lze usuzovat, že se žáci s BOV ve výuce př́liš nesetkávají. Pokud se už učitelé rozhodnou využít BOV, pak spíše v rámci praktických cvičení. Žáci se mohou do jisté míry setkávat s prvky BOV také v rámci vyučovací hodiny, zvláště pokud nemají v rámci výuky biologie hodinovou dotaci na praktická cvičení. U nabídky „jiné“ uváděli respondenti jako příklady exkurzi, terénní cvičení, popř. mimoškolní zájmovou činnost. Vyšší průměrné skóre u nabídky „seminář“ je dáno nižším počtem žáků navštěvujících výběrový seminář z biologie a také spíše negativním vyjádřením těchto žáků ke sledované kategorii.

Tab. 5: Průměrné skóre míry zkušenosti s realizací BOV ve vyučovacích jednotkách z pohledu žáků a učitelů

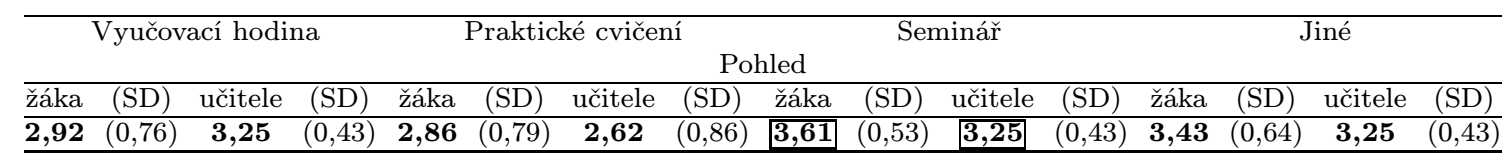

Poznámky: SD (standard deviation) - směrodatná odchylka. Výsledky párového t-testu viz tab. P5 a obr. 18 , korelační analýzy viz tab. P6 a obr. 18 v příloze. Sledované kategorie, u kterých se statisticky významně lišilo reflektování mezi dvěma skupinami i po korekci, jsou zvýrazněné tučně. Pokud bylo $d>0,80$, jsou př́íslušné hodnoty orámovány.

Relativně nízká frekvence využívání BOV souvisí především s její velkou časovou náročností (Kleve, 2007; Petr, 2014; Ješková et al., 2016; Radvanová et al., 2018). Pokud se již učitel rozhodne pro BOV, pak ji nejčastěji zařazuje právě do praktických cvičení (Petr et al., 2015 či Radvanová et al., 2018). Signifikantní rozdíly mezi reflektováním učitelů a žáků mohou být vysvětlitelné skutečností, že žáci jsou mnohem více kritičtí $\mathrm{k}$ nejčastěji využívaným výukovým metodám ve výuce biologie, a mají tak větší očekávání směrem k BOV. Dále je možné, že žáci patřičně nedoceňují snahu svých vyučujících implementovat BOV či její jednotlivé prvky dle svých možností do výuky biologie.

\section{NACVIČOVÁNí KROKŮ, JEŽ ODPOVÍDAJÍ BADATELSKÉMU CYKLU, VE VÝUCE BIOLOGIE A JEJICH ZAŘAZENÍ DO VYUČOVACÍCH JEDNOTEK}

Byla zkoumána míra využívání jednotlivých badatelských kroků a jejich zařazení do vyučovacích jednotek.

Učitelé i žáci uvádějí, že nejvíce aplikují jednotlivé kroky BOV v praktickém cvičení, přičemž nejvíce při něm nacvičují následující dovednosti - samostatně provádět pokus, zaznamenávat pozorování a měření, interpretovat získaná data a vyhodnocovat výsledky, samostatně shrnout hlavní poznatky a naformulovat závěry. Naopak nejméně jsou rozvíjeny dovednosti samostatně formulovat problém a hypotézu, naplánovat pokus. Žáci se obecně vyjadřovali signifikantně více negativně než jejich 
Tab. 6: Klasifikace badatelských dovedností a průměrné skóre míry jejich využívání v jednotlivých vyučovacích jednotkách z pohledu žáků a učitelů

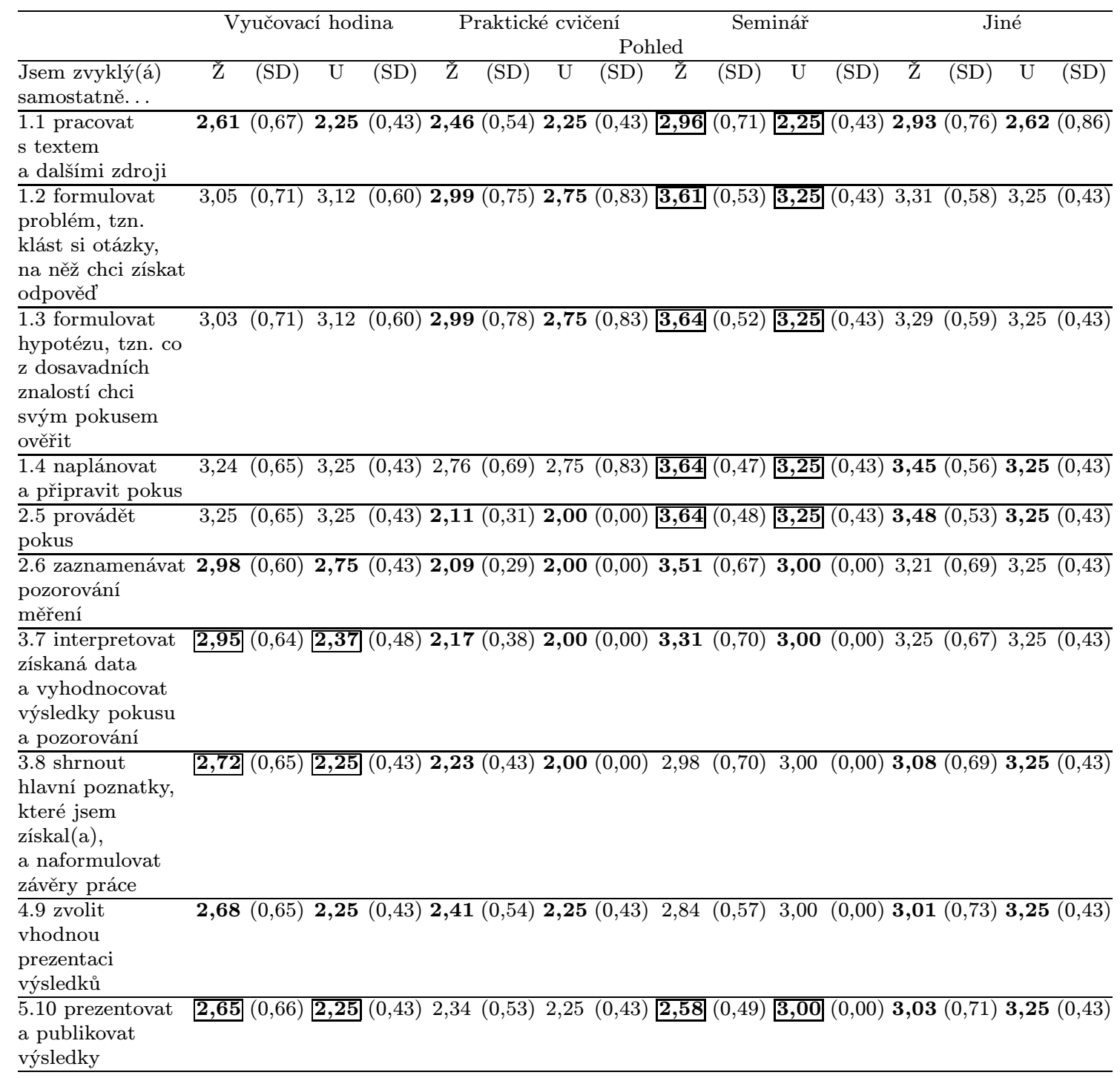

Poznámky: SD (standard deviation) - směrodatná odchylka, Ž - žák, U - učitel. Výsledky párového t-testu viz tab. P7 a obr. 19-28, korelační analýzy viz tab. P8 a obr. 19-28 v př́loze. Sledované kategorie, u kterých se statisticky významně lišilo reflektování mezi dvěma skupinami i po korekci, jsou zvýrazněné tučně. Pokud bylo $d>0,80$, jsou př́slušné hodnoty orámovány.

učitelé k tvrzením, že se věnují nácviku výše jmenovaných dovedností ve výuce biologie (viz tab. 6).

Komplexní úlohy zaměřené na rozvoj vyšších úrovní bádání tak nejsou ve výuce učiteli příliš využívány, přestože mnozí autoři doporučují jejich postupné nacvičování se žáky (Wenning, 2005, 2010; Činčera, 2013; Kireš et al., 2016). Také rozložení indexu badatelsky orientované výuky během šetření OECD/PISA 2015, popř. IEA/TIMSS 2015 napovídá rozdílnému využívání jednotlivých kroků BOV ve výuce přirodovědných předmětů (ČŠI, 2018a, 2018b). Zjištěná skutečnost by tedy mohla do jisté míry souviset s celou řadou omezení při realizaci BOV ve výuce (viz výše). Podle Petra (2014) je častější užití nižších úrovní bádání celkem logické. Umožňují totiž vyřešit dilema, kdy na jedné straně dovoluje učiteli vést žáky za určitým vzdělávacím cílem, daným např. vzdělávacím programem, a na druhé straně poskytuje potřebnou a dostatečnou volnost žákům pro badatelské aktivity. Také Kireš et al. (2016) doporučují do běžné výuky zařazovat aktivity z nižších úrovní bádání, protože 
poskytují žákovi jistou dávku samostatnosti, ale zároveň dostatek pomoci a vedení ze strany učitele, který drží průběh hodiny pevně v rukách. Nejvyšší úrovně bádání pak spatřují autoři jako vhodné zařadit u žáků, kteří jsou na tento způsob výuky dobře natrénovaní, resp. u žáků talentovaných se zájmem o přírodní vědy nebo při zadávání dlouhodobějších žákovských projektů. Jako další možnost pro využití vyšších úrovní badatelských aktivit se jeví použití ve třídě, kde jsou žáci zvyklí pracovat v heterogenních rovnocenných skupinách formou skupinového vyučování a disponují základními badatelskými dovednostmi (Kireš et al., 2016).

\section{PREFERENCE ZÍSKÁVÁNÍ INFORMACÍ ŽÁKY VE VÝUCE BIOLOGIE}

Zjištována byla také míra preferencí získávání informací žáky ve výuce biologie.

Žáci preferují ve výuce biologie spíše samostatné vyhledávání informací. Naopak učitelé uvedli, že žáci upřednostňují samostatné vyhledávání informací, jen pokud je dané téma zajímá. Obě uvedená zjištění jsou statisticky signifikantní (viz tab. 7).

Tohoto poznatku by se dalo využít při realizaci výuky s badatelskými prvky. Naše výsledky jsou v souladu s Kirešem et al. (2016), že žáci mohou provádět badatelské činnosti i prostřednictvím vyhledávání informací z rozličných zdrojů anebo studiem situací a použitím analogií a konstruováním modelů.

Tab. 7: Průměrné skóre míry preferencí pro způsob získávání informací ve výuce biologie z pohledu žáků a učitelů

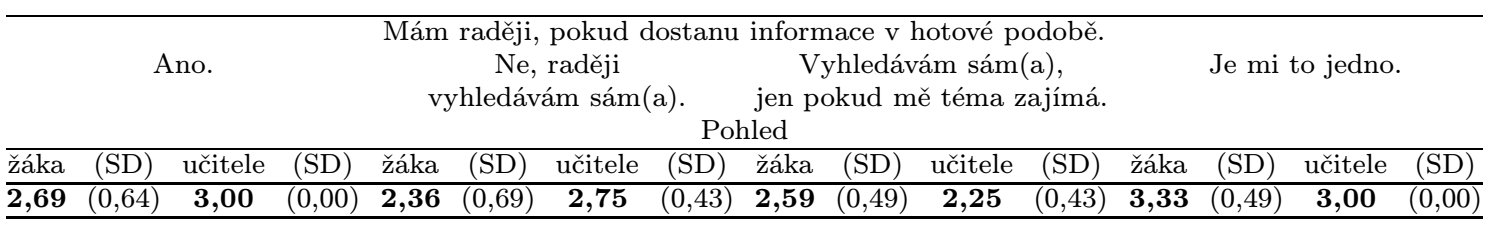

Poznámky: SD (standard deviation) - směrodatná odchylka. Výsledky párového t-testu viz tab. P9 a obr. 29, korelační analýzy viz tab. P10 a obr. 29 v př́loze. Sledované kategorie, u kterých se statisticky významně lišilo reflektování mezi dvěma skupinami i po korekci, jsou zvýrazněné tučně.

\section{KVALITATIVNÍ ANALÝZA}

\section{AKTIVITA 1 SŮl NAD ZLATO?}

Většina skupin správně uvedla neznámou látku jako vodu. Nesprávné odpovědi žáků souvisely s jejich nepozorností při čtení textu a nedostatečným zamyšlením se nad jeho obsahem. Na základě provedené obsahové analýzy shledali žáci text za odborný, jelikož byl napsán stroze, spisovně a zároveň věcným stylem. Museli se více soustředit na jeho obsah, protože se v textu vyskytovalo hodně odborných pojmů, matematicky vyjádřených informací a grafư. Většina žáků není zvyklá pracovat v hodině biologie s textem metodou I.N.S.E.R.T. Problém měli zejména vytvořit smysluplnou, rozvitou otázku k napsaným tvrzením, na kterou lze jednoznačně odpovědět. Většinou psali pouze holé otázky nebo hesla. V závěrečné reflexi žáci vnímali přínosnost a všeobecnou uplatnitelnost procvičovaných dovedností, avšak práce s textem pro ně byla náročná, a ne moc záživná.

\section{AKTIVITA 2 VoDNí ŠPEDITÉŘI}

Žáci převážně správně vysvětlili význam pojmu osmoregulace. Navržené výzkumné otázky se týkaly zejména souvislostí osmoregulace se stavbou, typem buňky a okol- 
ním prostředím. Většina žáků neměla problém zformulovat výzkumnou otázku, hypotézy a naplánovat postup experimentu a rozdělit si role ve skupině. Obtíže žákům občas dělal výběr pomůcek, odebrání vzorku, příprava různě koncentrovaných prostředí, navržení záznamové tabulky, dohodnutí počtu vzorků, opakování pozorování a časové rozvržení experimentu. Někteří žáci zapomněli popsat jednotlivé nákresy nebo nebyl ve tvaru buněk na první pohled patrný žádný rozdíl. Většina žáků potvrdila experimentem stanovené hypotézy. $\mathrm{V}$ opačném př́ípadě zdůvodnili svou neúspěšnost špatně připravenými roztoky či preparáty, nevystižením správného reakčního času buňky nebo chybným časovým rozvržením experimentu. Provedený pokus vyvolal v některých žácích nové otázky, na které chtěli získat odpovědi dalším experimentem. V závěrečné reflexi většinou žáky experiment bavil, i když byl náročný, protože museli vše dělat sami. Nejméně je zajímalo stanovovat výzkumnou otázku, hypotézy a zdůvodňovat postup a získané výsledky. Naopak nejvíce je bavilo plánovat, provádět a vyhodnocovat experiment. Zbylé tři úkoly vztahující se $\mathrm{k}$ této aktivitě dostali žáci vypracovat za domácí úkol.

\section{AkTivita 3 ČIstiČKA V LIDSKÉM TĚLE}

Žáci měli po zhlédnutí videa vypracovány odpovědi většinou správně a pečlivě. Problém měli se stanovením některých hypotéz. Největší obtíže činilo žákům nejenom zodpovědět otázky, které se týkaly stanovení hodnot osmolality tubulární tekutiny a okolního prostředí, ale i naformulovat průběh fyziologických pochodů, které jsou charakteristické pro jednotlivé oddíly nefronu. Téměř nikdo z žáků neměl odpovědi na tyto otázky kompletní. Nejčastěji jejich odpovědi postrádaly věcnost, odbornost a logiku. U některých žáků vyvolalo bádání nové otázky. V závěrečné reflexi většinou žáky zaujaly nově získané informace a složitost procesu tvorby moči v nefronu. Zároveň přiznali náročnost bádání, jelikož byli nuceni samostatně přemýšlet, logicky uvažovat a pracovat s informacemi. Žáci uváděli, že nejsou zvyklí pracovat v hodinách biologie s grafy a číst z nich potřebné údaje. Většinou dodrželi požadavky kladené na prezentaci. Během výstupu spolužáků si doplňovali chybějící údaje do svých pracovních listů. Při vyhodnocování výsledků prezentací postupovali žáci podle předem daných kritérií, na nedostatky upozorňovali věcně a taktně. $\mathrm{Na}$ závěr většinou prokázali uspokojivé znalosti z okruhu otázek, které měli samostatně zpracovat $\mathrm{v}$ části minulé hodiny a poté za domácí úkol.

\section{AKTIVITA 4 LEDVINY NEJSOU NA VŠECHNO SAMY}

Žáci správně vysvětlili význam pojmu exkrece vody. Nutné bylo korigovat výběr otázek žáků pro jejich následné ověřování, jelikož by bylo obtížné dohledat je v dostupných informačních zdrojích anebo je experimentálně ověřit s pomocí připravených pomůcek. Většina skupin si zvolila první variantu pokusu. Někteří žáci měli problém s navržením záznamové tabulky, popř. ji měli nepřehlednou či v ní chyběly určité údaje. U druhé varianty pokusu nebyla žádná skupina schopna si sama vybrat všechny potřebné pomůcky a naplánovat pracovní postup, problém měli i s rozvržením pokusu. Navržené záznamové tabulky byly chaotické, nepřehledné a občas chyběly i některé údaje. Chemickou podstatu pokusu nebyl schopen nikdo z žáků uspokojivě vysvětlit či převést do praxe. Na závěr žáci diskutovali mezi sebou jednotlivé experimentální postupy a výsledky. Někteří navrhovali další pokusy, kterými by bylo možné ověřit jejich hypotézy. 


\section{OMEZENÍ VÝZKUMU}

Výzkum byl realizován na relativně malém, záměrně vybraném vzorku žáků a učitelů, kteří pocházeli z gymnázií různého typu a zaměření. Protože měli respondenti rozdílné zkušenosti s BOV, byla snaha tuto skutečnost kompenzovat poskytnutím veškerých materiálů a podrobnou instruktáži $\mathrm{k}$ průběhu celého výzkumu. Získané výsledky není nutné plně zobecňovat, ale domníváme se, že mohou posloužit jako jeden z možných doplňujících pohledi̊ na současné využívání BOV v naší školní praxi, a především poskytnout učitelům náměty do výuky.

Statistická analýza dat byla provedena pomocí parametrických testů, byt̉ nejde o striktně normálně rozdělená data. Vycházíme ze skutečnosti, že použitý $t$-test je poměrně robustní a jeho použití je opodstatněné i pro případ Likertovy škály (viz de Winter \& Dodou, 2010). V př́padě složitějších analýz by bylo vhodné místo MS Excel využít statistický software, např. R (R core team, 2018).

\section{ZÁVĚR}

Cílem tohoto příspěvku bylo seznámit pedagogickou veřejnost s výsledky ověrování navržených badatelských aktivit, které byly získány na základě jejich reflektování z pohledu žáků vyššího gymnázia a jejich učitelů. Z hlediska metodologického zaměření výzkumu a jeho limitace se jednalo o orientační výzkumnou sondu. Žáci a jejich učitelé se názorově rozcházeli především u sledovaných kategorií náročnosti badatelských aktivit a poskytnutého dostatečného materiálního a technického zázemí. Nejvíce se pak shodovali ve vnímání srozumitelnosti a přínosnosti navržených badatelských aktivit, do jisté míry i poskytnutého času a množství informací.

Učitelé zapojeni do šetření př́liš nezařazují BOV do výuky biologie. Pokud se už pro ni rozhodnou, pak ji nejčastěji aplikují při praktickém cvičení k nácviku spíše nižších úrovní bádání. Tato zjištění, získaná na základě poskytnutých odpovědí žáků a učitelů v dotaznících, dokreslila i provedená kvalitativní analýza zaznamenaných odpovědí žáků v pracovních listech. Žákům totiž dělaly největší problémy následující badatelské dovednosti: samostatně formulovat výzkumnou otázku a hypotézy, naplánovat pokus, zdůvodňovat postup ověřování včetně získaných výsledků, popř. tyto výsledky věcně a zároveň srozumitelně naformulovat a následně o nich erudovaně diskutovat. Žáci navíc uvedli, že je tyto činnosti, zejména formulace výzkumné otázky a hypotéz, resp. zdůvodňování ověřování či argumentace výsledků, spíše nebavily a přišly jim náročné a mnohdy i zbytečné. Výše uvedené důvody ze strany žáků jsou pochopitelné, jelikož žáci nejsou zvyklí řešit v hodinách biologie komplexní badatelské úlohy. Žákům také činilo obtíže pracovat s odborným textem včetně získávání informací z předložených grafư, obrázků a schémat. K nácviku těchto obecně uplatnitelných badatelských dovedností by mohlo jistě napomoci častější využití zjištěných preferencí samostatného vyhledávání informací žáky. Zde však mohlo dojít k určitému zkreslení výsledků vlivem dezinterpretace obsahového významu tvrzení mezi respondenty. Záměrem totiž bylo zjistit u obou skupin respondentů preferenci získávání poznatků žáky ve výuce biologie z obecného pohledu, nikoliv pouze na základě praktického ověřování badatelských aktivit.

Výsledky realizovaného výzkumu tak do určité míry dokreslují domněnku, že je nutné se žáky postupně a cíleně nacvičovat jednotlivé badatelské kroky již v počátcích školního vzdělávání. Jedině tak se může žák stávat vyspělejším badatelem, a navíc v pozdějších letech by již nemusel nastat kýžený efekt v souvislosti se zvýšením 
trvalého zájmu žáků o přírodovědné předměty, přírodní vědy a profese z nich vycházející. Zjištěné údaje také korespondují se závěry posledního šetření OECD/PISA 2015. Na základě rozložení indexu badatelsky orientované výuky lze totiž konstatovat, že větší prostor $\mathrm{v}$ přrírodovědných hodinách je v Česku stále věnován metodám s převahou aktivity na straně učitele (též ČS̆I, 2018a).

Jednotlivé badatelské aktivity a doprovodné materiály včetně podrobnější statistické analýzy ziskaných dat v podobě shrnujicich tabulek a výsečových $i$ skládaných grafú jsou uloženy jako elektronická přiloha článku na webových stránkách časopisu.

\section{PODĚKOVÁNí}

Příspěvek vznikl s podporou projektu PRIMUS/17/HUM/11.

\section{LITERATURA}

Akcay, H. \& Yager, R. E. (2016). Students learning to use the skills by practicing scientists. Eurasia Journal of Mathematics, Science 85 Technology Education, 12(3), 513-525. DOI: 10.12973/eurasia.2015.1395a

Banchi, H. \& Bell, R. (2008). The many levels of inquiry. Science $\& 3$ Children, 46(2), $26-29$.

Blažek, R. (2017). Publikace s uvolněnými úlohami z mezinárodního šetření PISA 2015. Úlohy z př́rodovědné gramotnosti a metodika tvorby interaktivních úloh. Praha: ČS̆I.

Blažek, R. \& Příhodová, S. (2016). Mezinárodni šetřeni PISA 2015. Národni zpráva. Př́rodovědná gramotnost. Praha: ČŠI.

Cohen, J. (1988). Statistical power analysis for the behavioral sciences. USA: Lawrence Erlbaum Associates.

Comeaux, P. \& Huber, R. A. (2001). Students as scientists: Using interactive technologies and collaborative inquiry in an environmental science project for teachers and their students. Journal of science teacher education, 12(4), 235-252. DOI:

10.1023/A: 1014226110211

Činčera, J. (2013). Badatelé.cz: evaluační zpráva. Liberec: TU.

ČŠI. (2018a). Vliv složení tř́dy, metod uplatñovaných učitelem a využivání technologií na výsledky českých žákư. Sekundární analýza PISA 2015. Praha: ČŠI.

ČŠI. (2018b). Srovnání vybraných znaků méně úspěšných a velmi úspěšných tř́́d na základě výsledi mezinárodních šetřeni TIMSS 2015 a TIMSS 2011. Sekundární analýza. Praha: ČŚI.

De Winter, J. C. F. \& Dodou, D. (2010). Five-point Likert items: $t$-test versus Mann-Whitney-Wilcoxon. Practical Assessment, Research \&3 Evaluation, 15(11), 1-12.

Dostál, J. (2015a). Badatelsky orientovaná výuka: Pojetí, podstata, význam a př́nosy. Olomouc: UP. DOI: $10.5507 /$ pdf.15.24443935

Dostál, J. (2015b). Badatelsky orientovaná výuka: Kompetence učitelů k její realizaci $v$ technických a přírodovědných předmětech na základních školách. Olomouc: UP. DOI:10.5507/pdf.15.24445151

Eisenkraft, A. (2003). Expanding the 5E model. The Science Teacher, 70(6), 56-59. 
Fučík, P. \& Kuchař, V. (2012). Evaluace pilotního projektu: Vzdělávání učitelů př́rodopisu a biologie s tématikou badatelsky orientovaného vyučování. Praha: MŠMT.

Heflich, D. A., Dixon, J. K. \& Davis, K. S. (2001). Taking in to the field: The authentic integration of mathematics and technology in inquiry-based science instruction. Journal of computers in mathematics and science teaching, 20(1), 99-112.

Hošpesová, A. (2016). Badatelsky orientovaná výuka matematiky na 1. stupni základního vzdělávání. Orbis scholae, 10(2), 117-130. DOI: 10.14712/23363177.2017.5

Huber, R. A. \& Moore, Ch. J. (2001), A model for extending hand-on science to be inquiry based. School Science and Mathematics, 101(1), 32-41. DOI:

10.1111/j.1949-8594.2001.tb18187.x

Jarvis, T. (2008). Seed cities for science: Cross curricular hands-on science. Leicester: University of Leicester. Dostupné z http://www.pollen-europa.net

Ješková, Z., Lukáč, S., Šnajder, L., Guniš, J., Balogová, B. \& Kireš, M. (2016). Hodnotenie bádatelských zručností žiakov gymnázia. Scientia in educatione, 7(2), 48-70.

Kireš, M., Ješková, Z., Ganajová, M. \& Kimáková, K. (2016). Bádatelské aktivity $v$ prírodovednom vzdelávaní, čast A. Bratislava: ŚPÚ.

Kirschner, P. A., Sweller, J. \& Clark, R. E. (2006). Why minimal guidance during instruction does not work: An analysis of the failure of constructivist, discovery, problem-based, experiential, and inquiry-based teaching. Educational Psychologist, 41(2), 75-86. DOI: 10.1207/s15326985ep4102_1

Kleve, B. (2007). A study of teachers' views on the teaching and learning of mathematics, their intentions and their instructional practice. In Ch. Bergsten, B. Greveholm, H. S. Mâsøval \& F. Rønning (Eds.), Relating practice and research in mathematics education. Proceedings of NORMA 05, Fourth nordic conference on mathematics education (361-373). Trondheim: Tapir Academic Press.

Malcová, K. \& Janštová, V. (2018). Jak jsou hodnoceny jednotlivé obory žáky 2. stupně ZŠ a nižšího gymnázia? Biologie, chemie, zeměpis, 27(1), 23-34. DOI:

10.14712/25337556.2018.1.3

Marx, R. W., Blumenfeld, P. C., Krajcik, J. S., Fishman, B., Soloway, E., Geier, R. \& Tal, R. T. (2004). Inquiry-based science in the middle grades: Assessment of learning in urban systemic reform. Journal of Research in Science Teaching, 41(10), 1063-1080. DOI: $10.1002 /$ tea.20039

Petr, J., Ditrich, T., Zavodska, R. \& Papacek, M. (2015). Inquiry based biology education in the Czech Republic: A reflection of five years dissemination. In K. Maaß, B. Barzel, G. Törner, D. Wernish, D. Schäfer \& K. ReizKonzebovski (Eds.), Education the educators: International approaches to scaling-up professional development in mathematic and science education. Proceedings from the conference Education the Educators (118-124). Münster: WTM - Verlag für wissenschaftliche Texte und Medien.

Petr, J. (2014). Možnosti využití úloh z biologické olympiády ve výuce př́rodopisu a biologie. Inspirace pro badatelsky orientované vyučování. České Budějovice: Jihočeská univerzita, Pedagogická fakulta.

Průcha, J. (1987). Učení z textu a didaktická informace. Praha: Academia.

R Core Team. (2018). R: A language and environment for statistical computing.

$\mathrm{R}$ foundation for statistical computing, Vienna, Austria. Dostupné z

https://www.R-project.org/ 
Radvanová, S., Čižková, V. \& Martinková, P. (2018). Mění se pohled učitelů na badatelsky orientovanou výuku? Scientia in educatione, 9(1), 81-103.

Rastede, M. (2016). Forschendes lernen in der schule wagen: Herausforderungen für schüler und lehrer in einem neuen fach. Pädagogik, 68(3), 30-33.

Rokos, L., Zavodska, R., Bila, M. \& Rehackova, L. (2013). The respondent secondary school and university student and primary biological education. Journal of International Scientific Publication: Educational Alternatives, 11, 334-344.

DOI:10.15804/tner.2017.47.1.19

Science Education Curriculum Study. (2006). Colorado Springs. Dostupné z https://bscs.org/bscs-5e-instructional-model

Sjøberg, S. \& Schreiner, C. (2010). The ROSE project: an overview and key findings. Dostupné z http://roseproject.no/network/countries/norway/eng/nor-Sjoberg-Schreineroverview-2010.pdf

Soukup, P. (2013). Věcná významnost výsledků a její možnosti měření. Data a výzkum SDA Info/Data and Research - SDA Info, 7(2), 125-148. DOI:

10.13060/23362391.2013.127.2.41

Stokking, K., Schaaf, M., Jaspers, J. \& Erkens, G. (2004). Teachers' assessment of students' research skills. British Educational Research Journal, 30(1), 93-116. DOI: 10.1080/01411920310001629983

Šed’ová, K. (2014). Analýza kvalitativních dat. In R. Švaříček, K. Šed’ová, T. Janík, O. Kaščák, M. Miková, K. Nedbálková, P. Novotný, M. Sedláček \& J. Zounek, Kvalitativní výzkum v pedagogických vědách (207-247). Praha: Portál.

Vojtíšková, K. (2011). Školní úspěšnost a její (re)produkce na základní škole. Sociologický časopis/Czech Sociological Review, 47(5), 911-935.

Wenning, C. (2010). Levels of inquiry: Using inquiry spectrum learning sequences to teach science. Journal of Physics Teacher Education Online, 5(4), 11-20. Dostupné z http://www.phy.ilstu.edu/jpteo/issues/jpteo5(4)sum10.pdf.

Wenning, C. (2005). Levels of inquiry: Hierarchies of pedagogical practices and inquiry processes. Journal of Physics Teacher Education Online, 2(3), 3-11. Dostupné z http://www.phy.ilstu.edu/jpteo/issues/jpteo2(3)feb05.pdf.

Wu, H. \& Krajcik, J. S. (2006). Inscriptional practices in two inquiry-based classrooms: A case study of seventh graders' use of data tables and graphs. Journal of Research in Science Teaching, 43(1), 63-95. DOI: 10.1002/tea.20092

Sabina RAdVAnovÁ, sabina.radvanova@pedf.cuni.cz

PATRÍCIA MARTINKOVÁ, patricia.martinkova@pedf.cuni.cz

Univerzita Karlova, Pedagogická fakulta

Ústav výzkumu a rozvoje vzdělávání

Myslíkova 7, 11000 Praha 1, Česká republika

VĚRA ČížKovÁ, vera.cizkova@natur.cuni.cz

Univerzita Karlova, Př́rodovědecká fakulta

Katedra experimentální biologie rostlin

Viničná 7, 12844 Praha 2, Česká republika 